\title{
Propranolol as First Line Treatment for Life-threatening Diffuse Infantile Hepatic Hemangioma: a Case Report
}

Giulia Varrasso, ${ }^{a} \mathrm{MD}$, Amalia Schiavetti, ${ }^{\mathrm{a}} \mathrm{MD}$, Silvia Lanciotti, ${ }^{\mathrm{b}} \mathrm{MD}$, Maria Sapio, ${ }^{\mathrm{a}} \mathrm{MD}$, Eva Ferrara, ${ }^{a} \mathrm{MD}$, Alessandra De Grazia, ${ }^{\mathrm{a}} \mathrm{MD}$, and Anna Clerico, ${ }^{\mathrm{a}} \mathrm{PhD}$

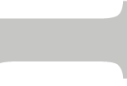

Affiliations: 'Dept.of Pediatrics -“Sapienza” University of Rome- Italy; ${ }^{b}$ Dept.of Radiology"Sapienza" University of Rome- Italy

Keywords: liver tumors, consumptive hypothyroidism, children

Address correspondence to: Giulia Varrasso, Department of Pediatrics, Policlinico Umberto I, viale Regina Elena 324, 00161 Rome, Italy, phone +39-06-49979348, fax +39-06-49979346 g.varrasso@policlinicoumberto1.it

List of abbreviations: IH-infantile hemangioma, IHH-infantile hepatic hemangioma, MRI-magnetic resonance imaging

Conflict of interest: The authors have no conflict of interest to disclose

Financial support: no honorarium, nor grant, nor other form of payment was given to anyone to produce the manuscript.

Mail addresses:

g.varrasso@policlinicoumberto1.it amalia.schiavetti@uniroma1.it lanciottisilvia@gmail.com marimari.sapio@gmail.com evaferrara81@gmail.com dr.degrazia@gmail.com anna.clerico@uniroma1.it

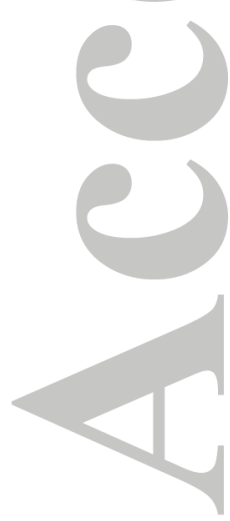

This article has been accepted for publication and undergone full peer review but has not been through the copyediting, typesetting, pagination and proofreading process which may lead to differences between this version and the Version of Record. Please cite this article as doi: 10.1002/hep.29028 


\section{Introduction}

Infantile hepatic hemangioma (IHH) is the most common benign tumor of the liver in the first year of age. Treatment for IHH is historically medical therapy including corticosteroids, interferon $\alpha$, vincristine and cyclophosphamide (1). Nevertheless, significant morbidity and mortality have been reported (2). Since 2010 few experiences of patients with IHH successfully treated with oral propranolol as second- or first line therapy are reported (3). Herein, we describe a particular case of life-threatening IHH successfully treated with oral propranolol as first line approach.

\section{Case Description}

A 4-month-old female was referred because of abdominal distension. Prenatal sonograms were normal. Abdominal examination was remarkable for hepatomegaly and prominent venous pattern. Skin examination was negative for hemangiomas. Abnormal laboratory findings were: hemoglobin $7.4 \mathrm{~g} / \mathrm{dL}$, total proteins $5.8 \mathrm{~g} / \mathrm{dL}$ (n.v.6.8-8.7), AST $94 \mathrm{IU} / \mathrm{mL}$ (n.v.16-65), $\gamma \mathrm{GT} 104$ UI/L (n.v.0-34), LDH 838 U/L (n.v.120-300). Abdominal ultrasound revealed marked hepatomegaly with multiple hypoechoic lesions. An abdomen dynamic contrast-enhanced magnetic resonance imaging (MRI) showed massive hepatomegaly with innumerable masses hypointense in $\mathrm{T} 1$ and hyperintense in $\mathrm{T} 2$ replacing most of the normal hepatic parenchyma (fig.1). Thyroid function tests revealed: TSH $69.96 \mu \mathrm{IU} / \mathrm{mL}$, (n.v.0.55-6.70), FT3 $1.6 \mathrm{pg} / \mathrm{mL}$ (n.v.1.50-6.40), FT4 1.62 ng/dL (n.v.0.80-1.80). Echocardiogram showed no signs of volume overload. A diagnosis of IHH diffuse pattern with consumptive hypothyroidism was made. The patient suddenly developed severe respiratory distress due to the rapidly increasing abdominal distension and she was transferred to Intensive Care Unit. Propranolol at $2 \mathrm{mg} / \mathrm{kg}$ per day and prednisone at $2 \mathrm{mg} / \mathrm{kg}$ per day through nasogastric tube were started. Thyroxine replacement

10.1 increased up to $12.8 \mu \mathrm{g} / \mathrm{kg}$ per day was also delivered. Her clinical conditions improved and she was weaned from $\mathrm{O}_{2}$ therapy. After 6 weeks a MRI evaluation demonstrated a mild reduction of the lesions, therefore prednisone was decreased to $1 \mathrm{mg} / \mathrm{kg}$ per day for 2 weeks and to 
$0.5 \mathrm{mg} / \mathrm{kg}$ per day for 2 more weeks while propranolol was continued. After 12 months a MRI showed an impressive involution of the liver lesions (Fig. 2), therefore thyroxine administration was slowly decreased. A complete regression of the lesions was documented after 24 months and propranolol was discontinued. No adverse effects of propranolol were observed. At present, the girl is three years old with normal neurological and auxologic development, under follow-up.

\section{Discussion}

The diffuse form of IHH has an extensive hepatic involvement with a near total replacement of the liver parenchyma by innumerable lesions. Massive hepatomegaly causes compression of the inferior vena cava and thoracic cavity, resulting in respiratory distress, abdominal compartment syndrome and multi-organ failure (2). Consumptive hypothyroidism is a rare complication of IHH (4). The mainstay of treatment for symptomatic IHH has traditionally included primarily corticosteroids, followed by interferon $\alpha$, vincristine and cyclophosphamide for resistant lesions (2). The use of these agents, however, may be associated with well-known side effects. Surgical approach including embolization, hepatic artery ligation, hepatic resection and liver transplantation has been reported for more severely ill children but it may be associated with a high rate of complications such as bleeding and liver necrosis (1). In 2008 propranolol was serendipitously discovered to promote regression of $\mathrm{IH}$; its use in cutaneous hemangioma is now considered as standard-of-care first-line systemic therapy (5). Propranolol was initially employed in IHH treatment as second-line therapy in patients resistant to conventional medical therapy. Since 2010 , sixteen patients successfully treated with propranolol as first-line approach have been published (3). All these patients presented cutaneous hemangiomas which were interestingly absent in our case. Furthermore, in our case propranolol was started in Intensive Care Unit through nasogastric tube.

In conclusion, we underline the impressive efficacy of propranolol in a life threatening situation and the safety of prolonged administration. 


\section{References}

1. Meyers R.L. Tumors of the liver in children. Surg Oncol 2007; 16:195-203.

2. Rialon KL, Murillo R, Fevurly RD, Kulungowski AM, Christison-Lagay ER, Zurakowski D, Kozakewich HP, Alomari AI, Fishman SJ. Risk factors for mortality in patients with multifocal and diffuse hepatic hemangiomas. J Pediatr Surg. 2015; 50:837-841.

3. Avagyan S, Klein M, Kerkar N, Demattia A, Blei F, Lee S, Rosenberg HK, Arnon R. Propranolol as a first-line treatment for diffuse infantile hepatic hemangioendothelioma. J Pediatr Gastroenterol Nutr. 2013; 56:e17-20.

4. Huang SA, Tu HM, Harney JW, Venihaki M, Butte AJ, Kozakewich HP, et al. Severe hypothyroidism caused by type 3 iodothyronine deiodinase in infantile hemangiomas. $\mathrm{N}$ Engl $\mathrm{J}$ Med. 2000; 343:185-89.

5. Léauté-Labrèze C, Dumas de la Roque E, Hubiche T, Boralevi F, Thambo JB, Taïeb A. Propranolol for severe hemangiomas of infancy. N Engl J Med. 2008; 358:2649-51.

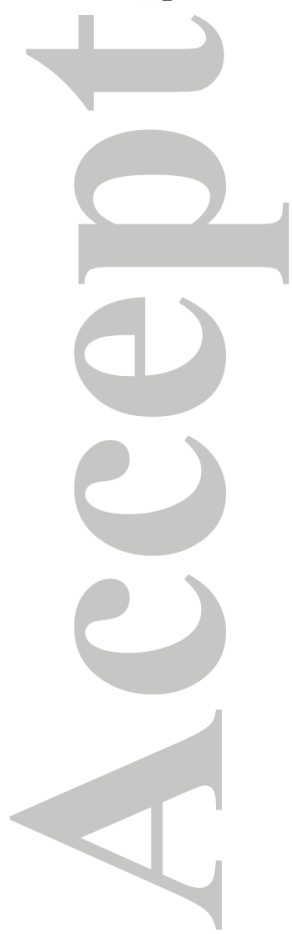




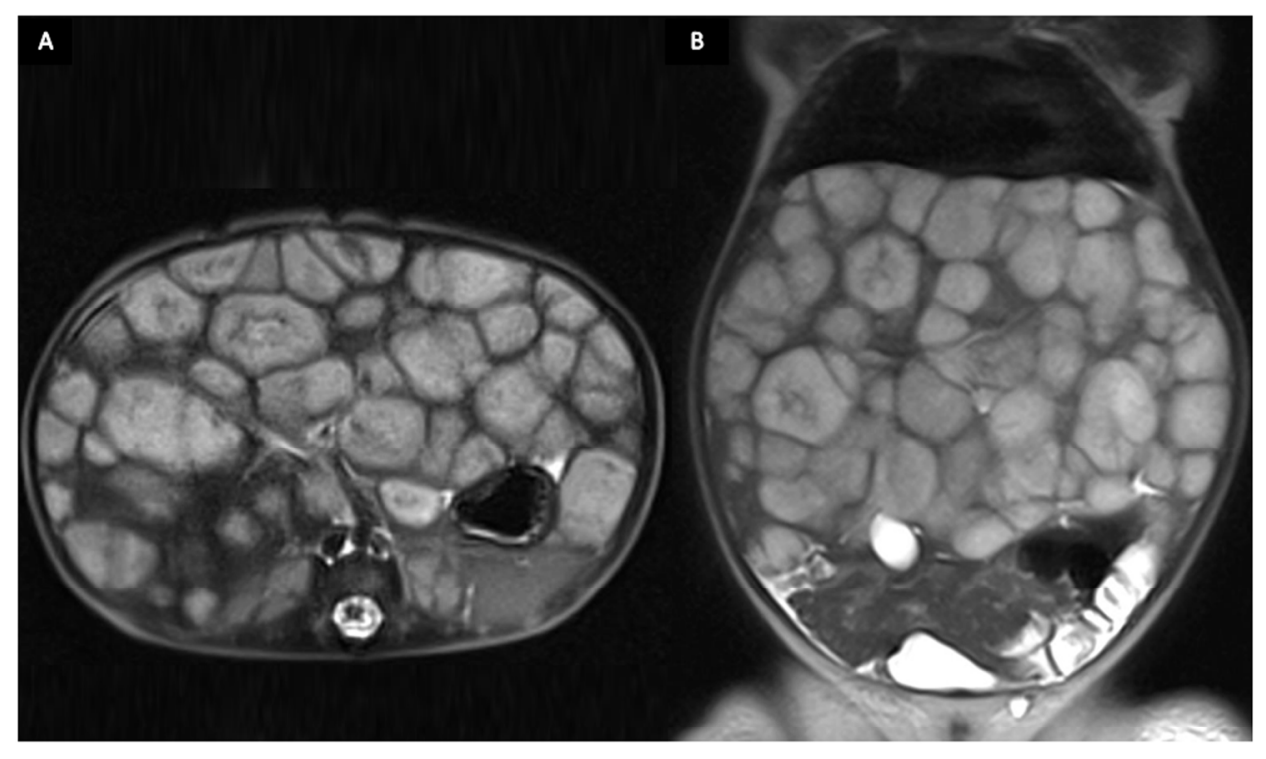

$254 \times 190 \mathrm{~mm}(300 \times 300 \mathrm{DPI})$

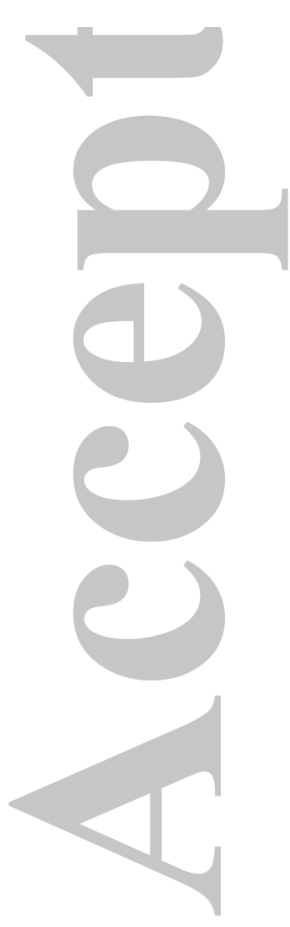

Hepatology

This article is protected by copyright. All rights reserved. 


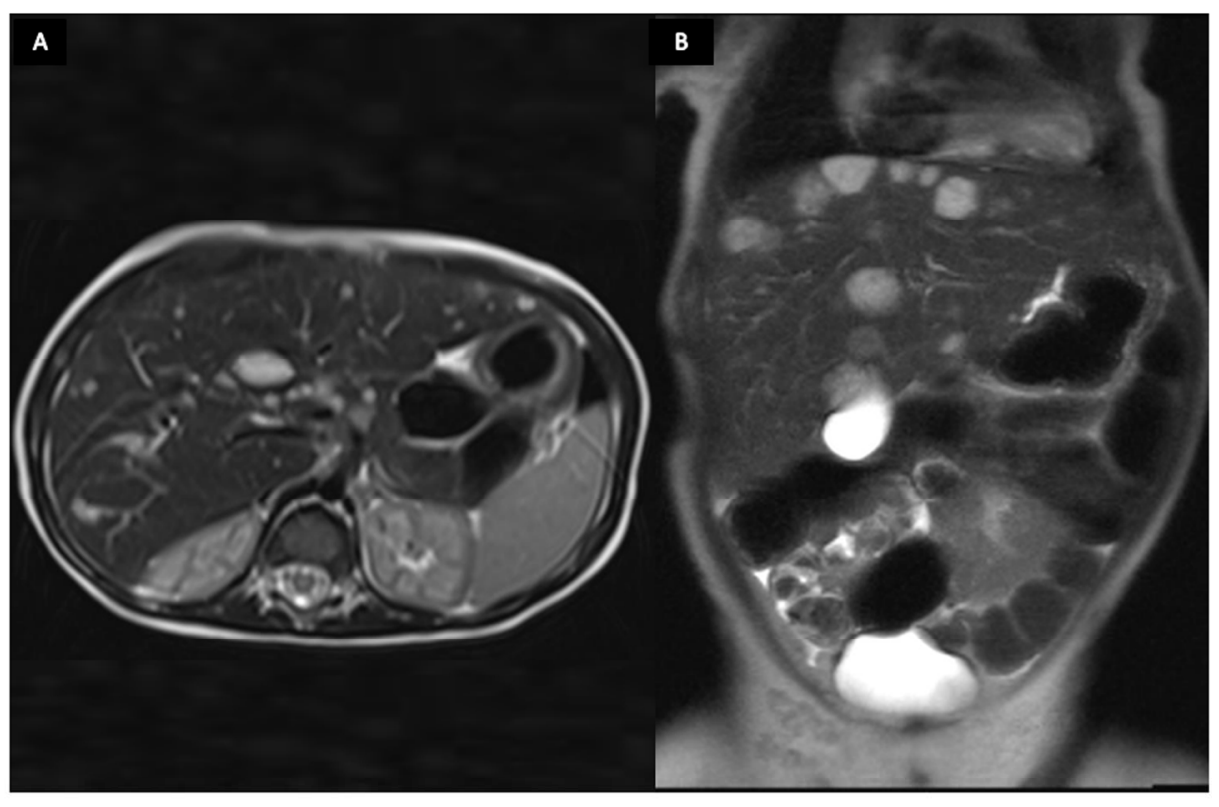

$254 \times 190 \mathrm{~mm}(300 \times 300 \mathrm{DPI})$

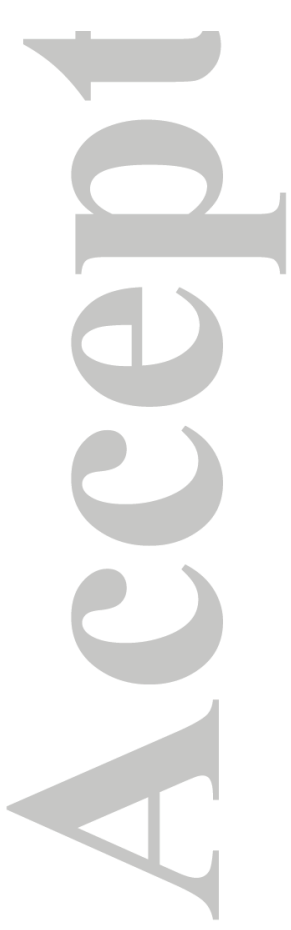

Hepatology

This article is protected by copyright. All rights reserved. 